The International Journal of Engineering and Science (IJES)

|| Volume || 6 || Issue || 5 || Pages || PP 39- 45 || 2017 ||

ISSN (e): $2319-1813$ ISSN (p): $2319-1805$

THE IJES

\title{
Fisher Theory and Stock Returns: An empirical investigation for industry stocks on Vietnamese stock market
}

\author{
Le Long Hau \\ College of Economics, Cantho University, Vietnam \\ Campus II, 3-2 street, Ninhkieu district, Cantho city, Vietnam
}

\begin{abstract}
-
This paper examines the Fisher hypothesis using 24 industry stocks in Vietnamese stock market. Empirical results in both ex post and ex ante models show a clear rejection of one-to-one relationship between stock returns and (actual/expected/unexpected) inflation, for all industry stock returns. Interestingly, the Fisher hypothesis that common stocks can provide a complete hedge against expected inflation is strongly rejected, given these findings. However, the results show that a number of industry stocks can provide a partial hedge against both ex post and expected inflation. This study has several implications for investors.
\end{abstract}

Keywords: industry stock returns, Fisher hypothesis, Vietnamese stock market, hedge

Date of Submission: 13 May 2017

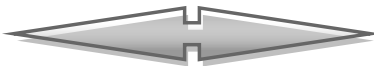

Date of Accepted: 24 May 2017

\section{INTRODUCTION}

It is believed that nominal stock returns are positively and (and even on a one-for-one basis) correlated with (expected or actual) inflation (Lintner, 1975; Groenewold, et al., 1997). This belief is grounded on the wellknown Fisher hypothesis in its ex ante form (Fisher, 1896; Fisher, 1930), assuming that in the long-run firms can increase their output prices in order to pass on the inflation to the customer (Mishkin, 1992; Boudoukh and Richardson, 1993). Given that stocks are claims on physical assets, or "real" assets, nominal stock returns must also co-vary positively with actual (ex post) inflation, suggesting that stocks can also provide a good hedge against unexpected inflation (Sharpe, 2002). These wide spread beliefs have been extensively investigated for stock markets around the world. Most empirical studies for developed stock markets document a significantly negative relationship between (real and nominal) stock returns and (actual, expected and unexpected) inflation (see, e.g., Lintner (1975); Bodie (1976); Fama and Schwert (1977); Gultekin (1983b)), obviously indicating a serious violation of the (extended) Fisher hypothesis. However, mixed findings are found for developing countries. Meanwhile a large number of studies provides evidence of a significant and positive stock returninflation relationship (see, e.g., Choudhry (2001); Spyrou (2004); Alagidede (2009); Alagidede and Panagiotidis (2010)), other studies find a significantly negative one (see, e.g., Chatrath, et al. (1997); Zhao (1999); Omran and Pointon (2001)). Generally, the Fisher hypothesis seems to be an empirical issue given that it holds in a limited number of cases.

For Vietnamese stock market, Hau et al. (2013) examines the hedging properties of stock market against inflation using the aggregate stock market index over July 2000-December 2011. Findings show that, for the whole period, stock returns are negatively related (although not statistically significant) to ex post inflation, but are statistically positively related to expected inflation. Moreover, Fisher hypothesis cannot be also rejected in the study. In this paper, we investigate the Fisher effects using industry stock indices in the Vietnamese stock market. This study can help to separate the effects of inflation on industry stock returns, thereby revealing the extent to which each industry stock portfolio in Vietnam can protect the wealth of investors against inflation. Empirical evidence from this study has important implications for both investors and policymakers.

The remainder of the paper is structured as follows. Section 2 presents the methodology. In section 3, data and summary statistics are shown. The empirical results are discussed in section 6. Finally, I conclude.

\section{METHODOLOGY}

Following previous studies (see, e.g., Nelson (1976); Boudoukh and Richardson (1993); Lintner (1975); Bodie (1976); Fama and Schwert (1977); Gultekin (1983b)), two empirical specifications are estimated. Firstly, the ex post relationship between nominal returns and inflation is examined in the first specification. In the second step, an ex ante model is conducted to investigate the relation between nominal stock returns and both expected and unexpected inflation rates with the second specification. 
Fisher Theory and Stock Returns: An empirical investigation for industry stocks on ..

The ex post relationship between the nominal asset return and inflation is represented as

$$
R_{t}=\varphi+\omega \pi_{t}+\epsilon_{t},
$$

where $\varphi$ and $\omega$ are coefficients and $\epsilon_{\mathrm{t}}$ is the error term.

The specification to test for ex ante relationship between the nominal asset return and inflation reads

$$
R_{t}=\alpha+\beta E_{t-1}\left(\pi_{t}\right)+\gamma U E_{t-1}\left(\pi_{t}\right)+n_{t},
$$

where $n_{t}$ is the error term, and $D E_{t-1}\left(\pi_{t}\right)$ denotes the unexpected component of inflation given information available at time $t-1$.

Using the approach by Fama and Schwert (1977), three cases for the hedging potential of an asset can be checked: asset is a complete hedge against expected inflation $(\beta=1.0)$, asset is a complete hedge against unexpected inflation $(\gamma=1.0$,$) and asset is considered as a complete hedge against inflation$ $(\beta=\gamma=1.0)$.

In specification (2), the expected and unexpected inflation is separated utilizing an ARIMA model (Box and Jenkins, 1970), commonly employed by other studies (e.g., Gultekin (1983b); Wahlroos and Berglund (1986); $\mathrm{Li}$, et al. (2010)). Since our focus is to examine the short-run influence of inflation on the asset returns, and not the feedback from returns to inflation, all regressions are estimated by OLS (Ordinary Least Squares). We use the Newey-West corrected covariance matrix when computing the test statistics in order to account for heteroskedasticity and residual autocorrelation (Newey and West, 1987).

\section{DATA}

Time series data are in monthly and are obtained from various sources. All industry stock price indices (VSSector Index) over the January 2012-December 2016 period are constructed and provided by Vietstock, a Vietnamese data provider. ${ }^{1}$ Consumer price index (CPI) for the same period is obtained from General Statististics Office of Vietnam. Time length of this research is dictated by data availability. Stock price indices and CPI are transformed into monthly returns and inflation rates, respectively using log changes. Both stock returns and inflation rates are stationary using the $\mathrm{ADF}$ test. ${ }^{2}$

\section{EMPIRICAL RESULTS}

Summary statistics for inflation and all industry stock returns are presented in table 1.

\begin{tabular}{|c|c|c|c|c|}
\hline & & & & Unit: \% \\
\hline & Mean & Std. & Min & Max \\
\hline Inflation & 0.344 & 0.489 & -0.440 & 2.200 \\
\hline Air transportation & 0.016 & 0.068 & -0.225 & 0.163 \\
\hline Construction materials & 0.011 & 0.031 & -0.060 & 0.097 \\
\hline Education services & 0.011 & 0.029 & -0.064 & 0.111 \\
\hline Services & 0.011 & 0.026 & -0.048 & 0.062 \\
\hline Plastics & 0.011 & 0.025 & -0.080 & 0.058 \\
\hline Construction & 0.010 & 0.041 & -0.071 & 0.158 \\
\hline Production and Business & 0.010 & 0.025 & -0.049 & 0.080 \\
\hline Seafood & 0.008 & 0.026 & -0.053 & 0.073 \\
\hline Energy & 0.008 & 0.021 & -0.042 & 0.091 \\
\hline Trade & 0.007 & 0.036 & -0.095 & 0.134 \\
\hline Steel & 0.007 & 0.031 & -0.076 & 0.079 \\
\hline Transportation & 0.007 & 0.027 & -0.063 & 0.069 \\
\hline Development Investment & 0.006 & 0.055 & -0.137 & 0.216 \\
\hline Pharmacy & 0.006 & 0.024 & -0.051 & 0.080 \\
\hline Technology & 0.005 & 0.026 & -0.051 & 0.071 \\
\hline Food & 0.005 & 0.023 & -0.049 & 0.060 \\
\hline Securities & 0.004 & 0.038 & -0.073 & 0.121 \\
\hline Investment and Construction & 0.004 & 0.032 & -0.070 & 0.091 \\
\hline Rubber & 0.004 & 0.022 & -0.057 & 0.091 \\
\hline Banking & 0.003 & 0.030 & -0.072 & 0.065 \\
\hline Oil & 0.002 & 0.040 & -0.085 & 0.067 \\
\hline Fertilizers & 0.002 & 0.030 & -0.094 & 0.010 \\
\hline Real estate & 0.001 & 0.030 & -0.052 & 0.069 \\
\hline Minerals & -0.007 & 0.029 & -0.094 & 0.067 \\
\hline No. of observations & \multicolumn{4}{|c|}{60} \\
\hline
\end{tabular}

Table 1. Descriptive statistics of industry stock returns and inflation

\footnotetext{
${ }^{1}$ Industries are classified using NAICS 2007 (North American Industry Classification System)

2 Stationarity of all variables is checked by both the Augmented Dickey-Fuller unit root test (ADF) (Dickey and Fuller, 1979). Optimal lag length selection for these tests is based on the Akaike Information Criterion (AIC) (Akaike, 1974). Results are available upon request.
} 
Fisher Theory and Stock Returns: An empirical investigation for industry stocks on ..

From the table, monthly inflation rates have a mean of $0.34 \%$ and a standard deviation of $0.49 \%$. For industry stock returns, the mean ranges from $0.001 \%$ to $0.016 \%$, and the minerals stocks have a negative return. In general, no outliers in data can be observed, showing the reliability of the estimated results.

Table 2 presents the regression results of stock returns on actual inflation rates for all industry stock returns. The results show a positive coefficient for all industries, ranging from 0.003 to 0.021 , except for plastic and pharmacy industries, yet the coefficient is statistically significant only 12 industries from $1 \%$ to $5 \%$ levels. Noticeably, the statistical test for the coefficient equal to one $\left(\mathrm{H}_{0}: \omega=1\right)$ is significant at the $1 \%$ level for all industry stocks, strongly rejecting the fact that stock returns may move in one-to-one correspondence with $e x$ post inflation. These results obviously show that industry stocks do not provide a complete hedge against the $e x$ post inflation, although some industry stocks (12 out of 24 industries) can provide a partial hedge against ex post inflation. These industry stocks are of trade, transportation, securities, real estate, investment and constructions, fertilizers, construction materials, banking, rubber, manufacturing and businesses, steel and energy.

Table 2. Regression results of stock returns on actual inflation for all industry stock returns

\begin{tabular}{|c|c|c|c|c|}
\hline \multirow[b]{2}{*}{ Industry stock returns } & \multicolumn{2}{|l|}{ Inflation } & \multirow[b]{2}{*}{ Adjusted $\mathrm{R}^{2}$} & \multirow{2}{*}{$\begin{array}{c}F \text {-value } \\
\mathrm{H}_{0}: \mathrm{Bs}=1\end{array}$} \\
\hline & Coefficient (B) & $\begin{array}{l}\text { Robust } \\
\text { std. }\end{array}$ & & \\
\hline Trade & $0.021 * * *$ & 0.006 & 0.088 & $24.455 * * *$ \\
\hline Transportation & $0.021 * * *$ & 0.004 & 0.140 & $51.821 * * *$ \\
\hline Securities & $0.020 * *$ & 0.008 & 0.072 & $16.883 * * *$ \\
\hline Real estate & $0.019 * *$ & 0.008 & 0.097 & $15.967 * * *$ \\
\hline Investment and constructions & $0.019 * * *$ & 0.006 & 0.088 & $20.499 * * *$ \\
\hline Fertilizers & $0.018 * *$ & 0.008 & 0.095 & $15.919 * * *$ \\
\hline Construction materials & $0.018 * *$ & 0.008 & 0.083 & $13.737 * * *$ \\
\hline Banking & $0.016 * *$ & 0.007 & 0.068 & $17.574 * * *$ \\
\hline Rubber & $0.014 * * *$ & 0.004 & 0.095 & $73.081 * * *$ \\
\hline Manufacturing and business & $0.014 * * *$ & 0.004 & 0.078 & $48.841 * * *$ \\
\hline Steel & $0.012 * *$ & 0.005 & 0.036 & $40.652 * * *$ \\
\hline Energy & $0.010 * *$ & 0.004 & 0.057 & $54.188 * * *$ \\
\hline Development Investment & 0.014 & 0.013 & 0.015 & $5.529 * * *$ \\
\hline Oils & 0.012 & 0.010 & 0.023 & $10.369 * * *$ \\
\hline Technology & 0.011 & 0.007 & 0.040 & $20.841 * * *$ \\
\hline Air transportation & 0.010 & 0.019 & 0.006 & $2.716 * * *$ \\
\hline Constructions & 0.010 & 0.011 & 0.015 & $7.769 * * *$ \\
\hline Services & 0.010 & 0.007 & 0.035 & $17.946^{* * *}$ \\
\hline Seafood & 0.007 & 0.005 & 0.017 & $34.846 * * *$ \\
\hline Food & 0.005 & 0.006 & 0.015 & $28.812 * * *$ \\
\hline Minerals & 0.004 & 0.007 & 0.005 & $22.662 * * *$ \\
\hline Education & 0.003 & 0.007 & 0.003 & $23.048 * * *$ \\
\hline Plastic & -0.001 & 0.005 & 0.001 & $40.334 * * *$ \\
\hline Pharmacy & -0.003 & 0.007 & 0.004 & $23.532 * * *$ \\
\hline No. of observations & & & & \\
\hline
\end{tabular}

Notes: *, ** and $* * *$ denote the significance levels of $10 \%, 5 \%$ and $1 \%$, respectively.

In the next part, the regression for industry stock returns on expected and unexpected inflation is implemented. In order to decompose actual inflation into expected inflation and unexpected inflation, the autoregressive model, $\operatorname{AR}(1)$, is employed as

$$
\operatorname{AR}(1): \pi_{\mathrm{t}}=0,245+0,259 \pi_{\mathrm{t}-1}+\varepsilon_{\mathrm{t}}
$$

Regression results for stock returns on expected and unexpected inflation rates for all industry stocks are reported in table 3. As can be seen from the table, the coefficients on expected returns share a similar pattern with those on actual inflation, i.e., they all are positive, except for plastic and pharmacy industries, and for only 12 out of 24 industries the coefficient is statistically significant from $1 \%$ to $5 \%$ level. In terms of size, these coefficients are vis-à-vis slightly greater than those on actual inflation are, ranging from 0.04 to 0.08 , implying that those industry stocks provide a better hedge against expected inflation than they do against actual inflation. Regarding the unexpected inflation, none of the coefficients for industry stocks is statistically significant at the traditional levels with the exception of industry "Development Investment" (i.e., the coefficient is negative and statistically significant at the $10 \%$ significance level). Hence, it can be concluded that industry stocks cannot hedge unexpected inflation. 
Fisher Theory and Stock Returns: An empirical investigation for industry stocks on ..

Table 3. Regression results of stock returns on expected and unexpected inflation for all industry stock returns

\begin{tabular}{lrrrrr}
\hline & \multicolumn{2}{c}{ Expected inflation } & \multicolumn{2}{c}{ Unexpected inflation } & \\
\cline { 2 - 4 } Industry & Coefficients $(\beta)$ & $\begin{array}{c}\text { Robust } \\
\text { std. }\end{array}$ & Coefficients $(\mathcal{Y})$ & $\begin{array}{c}\text { Robust } \\
\text { std. }\end{array}$ & Adjusted $\mathrm{R}^{2}$ \\
\hline Trade & $0.081^{* * *}$ & 0.024 & 0.001 & 0.008 & 0.089 \\
Transportation & $0.080^{* * *}$ & 0.017 & -0.003 & 0.011 & 0.143 \\
Securities & $0.074^{* * *}$ & 0.024 & -0.007 & 0.008 & 0.167 \\
Real estate & $0.073^{* *}$ & 0.030 & 0.002 & 0.009 & 0.185 \\
Investment and constructions & $0.073^{* *}$ & 0.029 & -0.005 & 0.015 & 0.065 \\
Fertilizers & $0.071^{* *}$ & 0.033 & -0.009 & 0.013 & 0.196 \\
Construction materials & $0.071^{* *}$ & 0.030 & 0.001 & 0.009 & 0.149 \\
Banking & $0.060^{* *}$ & 0.029 & -0.001 & 0.007 & 0.068 \\
Rubber & $0.052^{* * *}$ & 0.017 & -0.007 & 0.010 & 0.087 \\
Manufacturing and business & $0.052^{* * *}$ & 0.014 & 0.006 & 0.005 & 0.136 \\
Steel & $0.047^{* *}$ & 0.020 & 0.009 & 0.012 & 0.053 \\
Energy & $0.040^{* *}$ & 0.016 & 0.002 & 0.008 & 0.060 \\
Development Investment & 0.011 & 0.025 & $-0.009 *$ & 0.005 & 0.024 \\
Oils & 0.053 & 0.052 & -0.002 & 0.009 & 0.015 \\
Technology & 0.048 & 0.036 & 0.017 & 0.013 & 0.061 \\
Air transportation & 0.042 & 0.027 & -0.011 & 0.007 & 0.078 \\
Constructions & 0.039 & 0.076 & -0.028 & 0.027 & 0.049 \\
Services & 0.039 & 0.045 & 0.010 & 0.015 & 0.054 \\
Seafood & 0.035 & 0.029 & 0.006 & 0.006 & 0.035 \\
Food & 0.026 & 0.020 & -0.008 & 0.006 & 0.038 \\
Minerals & 0.021 & 0.023 & 0.003 & 0.006 & 0.018 \\
Education services & 0.017 & 0.025 & 0.011 & 0.009 & 0.033 \\
Plastic & -0.002 & 0.019 & -0.001 & 0.009 & 0.003 \\
Pharmacy & -0.012 & 0.028 & -0.003 & 0.004 & 0.016 \\
\hline No. of observations & & & & & \\
\hline
\end{tabular}

Notes: $*, * *$ and $* * *$ denote the significance levels of $10 \%, 5 \%$ and $1 \%$, respectively.

Results of statistical tests for Fisher hypothesis, a one-to-one relationship between industry stock returns and (expected/unexpected and either) inflation, are shown in table 4. As for table 4, all $t$-tests for coefficients on expected inflation equal to $1.0\left(\mathrm{H}_{0}: \beta=1\right)$ are statistically significant at the $1 \%$ level, showing a clear rejection of Fisher hypothesis for all industry stocks. In other words, a one-to-one relationship between stock returns and the ex-ante inflation for all industries is strongly rejected. Also, $t$-tests for coefficients on unexpected inflation equal to $1.0\left(\mathrm{H}_{0}: Y=1\right)$ are statistically significant at the $1 \%$ levels, reflecting the fact that industry stock returns do not move in a one-to-one fashion with unexpected inflation. Finally, it can be seen that both coefficients on expected and unexpected inflation are found to be statistically jointly indistinguishable from unity at the significance level of $1 \%$ using an $F$-test $\left(\mathrm{H}_{0}: \beta=\gamma=1\right)$.

Table 4. Results of $F$-test and $t$-test for Fisher effects for all industry stock returns

\begin{tabular}{|c|c|c|c|c|}
\hline \multirow[b]{2}{*}{ Industry } & $t$-value & $t$-value & \multicolumn{2}{|c|}{$F$-value } \\
\hline & $\mathrm{H}_{0}: \beta=1$ & $\mathrm{H}_{0}: Y=1$ & $\mathrm{H}_{0}: 9$ & $=Y=1$ \\
\hline Trade & $35.44 * * *$ & $137.85 * * *$ & & $9.888^{* * * *}$ \\
\hline Transportation & $54.15 * * *$ & $87.98 * * *$ & & $6.433 * * *$ \\
\hline Investment and constructions & $35.20 * * *$ & $123.69 * * *$ & & $8.249 * * *$ \\
\hline Real estate & $30.59 * * *$ & $114.19 * * *$ & & $6.535^{* * *}$ \\
\hline Securities & $31.84 * * *$ & $66.19 * * *$ & & $2.468 * * *$ \\
\hline Construction materials & $89.44 * * *$ & $27.06^{* * *}$ & & $3.989 * * *$ \\
\hline Fertilizers & $27.60 * * *$ & $120.76^{* * *}$ & & $7.714 * * *$ \\
\hline Banking & $34.97 * * *$ & $132.25 * * *$ & & $8.918^{* * *}$ \\
\hline Development Investment & $18.33 * * *$ & $107.87 * * *$ & & $6.354 * * *$ \\
\hline Manufacturing and business & $54.63 * * *$ & $117.04 * * *$ & & $9.741 * * *$ \\
\hline Rubber & $68.10 * * *$ & $213.09 * * *$ & & $29.391 * * *$ \\
\hline Oils & $26.17 * * *$ & $78.43 * * *$ & & $3.169 * * *$ \\
\hline Steel & $48.93 * * *$ & $80.53 * * *$ & & $4.503 * * *$ \\
\hline Technology & $36.14 * * *$ & $140.52 * * *$ & & $9.876^{* * *}$ \\
\hline Energy & $55.60 * * *$ & $124.06^{* * *}$ & & $6.993 * * *$ \\
\hline Education services & $39.51 * * *$ & $189.14 * * *$ & & $17.957 * * *$ \\
\hline Air transportation & $12.61 * * *$ & $37.67 * * *$ & & $1.049 * * *$ \\
\hline Constructions & $21.49 * * *$ & $66.78 * * *$ & & $2.644 * * *$ \\
\hline Services & $33.82 * * *$ & $173.24 * * *$ & & $15.063^{* * *} *$ \\
\hline Seafood & $48.70 * * *$ & $155.79 * * *$ & & $13.647 * * *$ \\
\hline Food & $40.45 * * *$ & $184.01 * * *$ & & $16.979 * * *$ \\
\hline Minerals & $11.09 * * *$ & $111.52 * * *$ & & $7.006^{* * * *}$ \\
\hline Plastic & $42.50 * * *$ & $112.36^{* * * *}$ & & $7.170 * * *$ \\
\hline Pharmacy & $39.10^{* * *}$ & $239.23 * * *$ & & $32.738 * * *$ \\
\hline
\end{tabular}

Notes: $*, * *$ and $* * *$ denote the significance levels of $10 \%, 5 \%$ and $1 \%$, respectively. 
Fisher Theory and Stock Returns: An empirical investigation for industry stocks on ..

To sum up, all findings show a strong rejection of Fisher hypothesis both in ex post and ex ante models for all industry stocks. These results imply that common stocks of all industries in Vietnamese stock market cannot provide a complete hedge against inflation (ex post, ex ante and unexpected inflation). Nevertheless, findings indicate that some industry stocks (12 out of 24 industries) can provide a partial hedge (although relatively small) against both actual and expected inflation rates. These industry stocks comprise of trade, transportation, securities, real estate, investment and constructions, fertilizers, construction materials, banking, rubber, manufacturing and businesses, steel and energy. For surprises in inflation, no industry stock can provide hedge.

\section{CONCLUSIONS}

This paper examines the inflation-hedging properties of 24 industry stocks in Vietnamese stock market. Empirical results show that 12 out of 24 industry stock returns have a positive and statistically significant relationship with ex post inflation, but the one-to-one relationship between stock returns and actual inflation is strongly rejected for all industry stocks. These results indicate that a number of industry stocks can provide a partial hedge against actual inflation. Estimating an ex ante model, similar to the ex post model only stock returns of 12 industries are statistically positively related to expected inflation, yet the size of coefficients is vis$\grave{a}$-vis greater than that in the ex post model. Reversely, almost all but one industry stock returns are found to be statistically significant related to unexpected inflation. Findings show a clear rejection of either the Fisher hypothesis of a one-to-one relationship between stock returns and the ex-ante inflation, or a complete hedge against surprises in inflation of stocks.

Taken all together, the present study has several implications. In general, common stocks for a number of industries in Vietnam can provide a partial hedge against actual and expected inflation rates, while almost no industry stocks can hedge against unexpected inflation. Interestingly, statistical evidence strongly rejects the Fisher hypothesis for all industry stocks in both ex post and ex ante models. These results provides more empirical evidence on the Fisher theory validation.

\section{REFERENCES}

[1]. Akaike, H., 1974. A new look at the statistical model identification. Automatic Control, IEEE Transactions on 19, 716-723

[2]. Al-Khazali, O.M., and Pyun, C.S., 2004. Stock prices and inflation: new evidence from the Pacific-Basin countries. Review of Quantitative Finance and Accounting 22, 123-140.

[3]. Alagidede, P., 2009. Relationship between stock returns and inflation. Applied Economics Letters 16, 1403-1408.

[4]. Alagidede, P., and Panagiotidis, T., 2010. Can common stocks provide a hedge against inflation? Evidence from African countries. Review of Financial Economics 19, 91-100.

[5]. Ang, A., Bekaert, G., and Wei, M., 2007. Do macro variables, asset markets, or surveys forecast inflation better? Journal of Monetary Economics 54, 1163-1212.

[6]. Bakshi, G.S., and Chen, Z., 1996. Inflation, asset prices, and the term structure of interest rates in monetary economics. Review of Financial Studies 9, 241-275.

[7]. Bartlett, M. S., 1995. An introduction to stochastic processes: with special reference to methods and applications. Cambridge: Cambridge University Press.

[8]. Bodie, Z., 1976. Common stocks as a hedge against inflation. The Journal of Finance 31, 459-470.

[9]. Boudoukh, J., and Richardson, M., 1993. Stock returns and inflation: A long-horizon perspective. The American Economic Review 83, 1346-1355.

[10]. Box, G. E. P., and Jenkins, G. M. , 1970. Time Series Analysis, Forecasting and Control. Holden Day, San Francisco.

[11]. Brennan, M.J., and Schwartz, E.S., 1978. Corporate income taxes, valuation, and the problem of optimal capital structure. Journal of Business 103-114.

[12]. Buddhari, A., and Chensavasdijai, V., 2003. Inflation dynamics and its implications for monetary policy. Bank of Thailand Discussion Paper 9, 2003.

[13]. Camen, U., 2006. Monetary policy in Vietnam: the case of a transition country. Bank for International Settlements Press \& Communications CH 4002 Basel, Switzerland 232.

[14]. Chantanahom, P., Poonpatpibul, C., and Vongsinsirikul, P., 2004. Exploring Inflation in Thailand: Through Sectoral Price Setting Behavior and Underlying Trend. Bank of Thailand.

[15]. Chatrath, A., Ramchander, S., and Song, F., 1997. Stock prices, inflation and output: evidence from India. Applied Financial Economics 7, 439-445.

[16]. Choudhry, T., 2001. Inflation and rates of return on stocks: evidence from high inflation countries. Journal of International Financial Markets, Institutions and Money 11, 75-96.

[17]. Choudhry, T., and Pimentel, R.C., 2010. Do Stock Returns Hedge against High and Low Inflation? Evidence from Brazilian Companies. The Review of Finance and Banking 2, 061-076.

[18]. Cohn, R.A., and Lessard, D.R., 1981. The effect of inflation on stock prices: international evidence. The Journal of Finance 36, 277289.

[19]. Cozier, B.V., and Rahman, A.H., 1988. Stock returns, inflation, and real activity in Canada. Canadian Journal of Economics 759774.

[20]. Crosby, M., 2001. Stock returns and inflation. Australian Economic Papers 40, 156-165.

[21]. D'Agostino, R.B., Belanger, A., and D'Agostino Jr, R.B., 1990. A suggestion for using powerful and informative tests of normality. The American Statistician 44, 316-321.

[22]. Danthine, J.P., and Donaldson, J.B., 1986. Inflation and asset prices in an exchange economy. Econometrica: Journal of the Econometric Society 585-605.

[23]. De Alessi, L., 1964. Do Business Firms Gain From Inflation? The Journal of Business 37, 162-166.

[24]. De Alessi, L., 1975. Do business firms gain from inflation? Reprise. The Journal of Business 48, $264-266$. 
Fisher Theory and Stock Returns: An empirical investigation for industry stocks on ..

[25]. Dickey, D.A., and Fuller, W.A., 1979. Distribution of the estimators for autoregressive time series with a unit root. Journal of the American Statistical Association 427-431.

[26]. Ely, D.P., and Robinson, K.J., 1997. Are stocks a hedge against inflation? International evidence using a long-run approach. Journal of international money and Finance 16, 141-167.

[27]. Endo, T., 2000. Thailand: Selected Issues. International Monetary Fund.

[28]. Engsted, T., and Tanggaard, C., 2002. The relation between asset returns and inflation at short and long horizons. Journal of International Financial Markets, Institutions and Money 12, 101-118.

[29]. Fama, E.F., 1981. Stock returns, real activity, inflation, and money. The American Economic Review 71, 545-565.

[30]. Fama, E.F., and Schwert, G.W., 1977. Asset returns and inflation. Journal of Financial Economics 5, 115-146.

[31]. Firth, M., 1979. The relationship between stock market returns and rates of inflation. The Journal of Finance 34, 743-749.

[32]. Fisher, I., 1896. Appreciation and Interest: A Study of the Influence of Monetary Appreciation and Depreciation on the Rate of Interest with Applications to the Bimetallic Controversy and the Theory of Interest. Pub. for the American economic association by the Macmillan company

[33]. Fisher, I., 1930. The Theory of Interest. MacMillan, New York.

[34]. Fisher, J.D., and Webb, R.B., 1992. Current issues in the analysis of commercial real estate. Real Estate Economics 20, 211-227.

[35]. Floros, C., 2008. Stock returns and inflation in Greece. Applied Econometrics and International Development, Vol. 4, No. 2, 2004.

[36]. Fuller, W.A., 1995. Introduction to statistical time series. Wiley-Interscience.

[37]. Geske, R., and Roll, R., 1983. The fiscal and monetary linkage between stock returns and inflation. The Journal of Finance 38, 1-33.

[38]. Groenewold, N., O'Rourke, G., and Thomas, S., 1997. Stock returns and inflation: a macro analysis. Applied Financial Economics 7, 127-136.

[39]. Gultekin, N.B., 1983a. Stock market returns and inflation forecasts. Journal of Finance 663-673.

[40]. Gultekin, N.B., 1983b. Stock market returns and inflation: Evidence from other countries. Journal of Finance 49-65.

[41]. Ha, P., 2010. Rational Bubbles in the Vietnamese Stock Market and the Relationship Between Monetary Policy and Stock Returns. Faculty of Economics, Thammasat University.

[42]. Hau, L.L., Dalina, A., Annaert, J., and De Ceuster, Marc J.K., 2013. Do stocks hedge inflation? Vietnamese and Thai evidence. International Research Journal of Applied Finance 10, 1278-1309.

[43]. Hess, P.J., and Lee, B.S., 1999. Stock returns and inflation with supply and demand disturbances. Review of Financial Studies 12 , 1203-1218.

[44]. Hondroyiannis, G., and Papapetrou, E., 2006. Stock returns and inflation in Greece: A Markov switching approach. Review of Financial Economics 15, 76-94.

[45]. Jaffe, J.F., and Mandelker, G., 1976. The "Fisher effect" for risky assets: An empirical investigation. The Journal of Finance 31, 447-458.

[46]. Jirasakuldech, Benjamas, Emekter, Riza, and Rao, Ramesh P, 2008. Do Thai stock prices deviate from fundamental values? PacificBasin Finance Journal 16, 298-315.

[47]. Jongwanich, J., and Park, D., 2011. Inflation in developing Asia: pass- through from global food and oil price shocks. Asian- Pacific Economic Literature 25, 79-92.

[48]. Kaul, G., 1987. Stock returns and inflation: The role of the monetary sector. Journal of financial economics 18, 253-276.

[49]. Kaul, G., 1990. Monetary regimes and the relation between stock returns and inflationary expectations. Journal of Financial and Quantitative Analysis 25, 307-321.

[50]. Kessel, R.A., and Alchian, A.A., 1960. The meaning and validity of the inflation-induced lag of wages behind prices. The American Economic Review 50, 43-66.

[51]. Khil, J., and Lee, B.S., 2000. Are common stocks a good hedge against inflation? Evidence from the Pacific-rim countries. PacificBasin Finance Journal 8, 457-482.

[52]. Kim, J.H., and Ryoo, H.H., 2011. Common stocks as a hedge against inflation: Evidence from century-long US data. Economics Letters 113, 168-171.

[53]. Kwiatkowski, D., Phillips, P.C.B., Schmidt, P., and Shin, Y., 1992. Testing the null hypothesis of stationarity against the alternative of a unit root: How sure are we that economic time series have a unit root? Journal of Econometrics 54, 159-178.

[54]. Lee, B.S., 1989. Solving, estimating, and testing a nonlinear stochastic equilibrium model, with an example of the asset returns and inflation relationship. Journal of economic dynamics and control 13, 499-531.

[55]. Lee, B.S., 2003. Asset returns and inflation in response to supply, monetary, and fiscal disturbances. Review of Quantitative Finance and Accounting 21, 207-231.

[56]. Lee, SR, Tang, DP, and Wong, K.M., 2000. Stock returns during the German hyperinflation. The Quarterly Review of Economics and Finance 40, 375-386.

[57]. Li, L., Narayan, P.K., and Zheng, X., 2010. An analysis of inflation and stock returns for the UK. Journal of International Financial Markets, Institutions and Money 20, 519-532.

[58]. Lintner, J., 1975. Inflation and security returns. The Journal of Finance 30, 259-280.

[59]. Ljung, G.M., and Box, G.E.P., 1978. On a measure of lack of fit in time series models. Biometrika 65, 297-303.

[60]. Loungani, P., and Swagel, P., 2001. Sources of inflation in developing countries. International Monetary Fund.

[61]. Marshall, D.A., 1992. Inflation and asset returns in a monetary economy. Journal of Finance 1315-1342.

[62]. Mishkin, F.S., 1992. Is the Fisher effect for real?: A reexamination of the relationship between inflation and interest rates. Journal of Monetary Economics 30, 195-215.

[63]. Mohanty, MS, and Klau, M., 2001. What determines inflation in emerging market economies? BIS Papers 8, 1-38.

[64]. Morrison, W.M., 2003. Thailand-US Economic Relations: An Overview, Congressional Research Service [Library of Congress].

[65]. Najand, M., and Noronha, G., 1998. Causal relations among stock returns, inflation, real activity, and interest rates: Evidence from Japan. Global Finance Journal 9, 71-80.

[66]. Narayan, S., and Narayan, P.K., 2012. Do US Macroeconomic Conditions Affect Asian Stock Markets? Journal of Asian Economics.

[67]. Nelson, C.R., 1976. Inflation and rates of return on common stocks. The Journal of Finance 31, 471-483.

[68]. Nelson, C.R., and Plosser, C.R., 1982. Trends and random walks in macroeconmic time series: some evidence and implications. Journal of Monetary Economics 10, 139-162.

[69]. Newey, W.K., and West, K.D., 1987. A simple, positive semi-definite, heteroskedasticity and autocorrelation consistent covariance matrix. Econometrica: Journal of the Econometric Society 703-708.

[70]. Nguyen, H.M., Cavoli, T., and Wilson, J.K., 2012. The Determinants of Inflation in Vietnam, 2001-09. ASEAN Economic Bulletin $29,1-14$ 
[71]. Omran, M., and Pointon, J., 2001. Does the inflation rate affect the performance of the stock market? The case of Egypt. Emerging Markets Review 2, 263-279.

[72]. Phillips, P.C.B., 1987. Time series regression with a unit root. Econometrica: Journal of the Econometric Society $277-301$.

[73]. Plasmans, J., 2006. Modern linear and nonlinear econometrics. Springer Verlag.

[74]. Roache, S.K., and Attie, A.P., 2009. Inflation Hedging for Long-Term Investors. International Monetary Fund.

[75]. Sharpe, S.A., 2002. Reexamining stock valuation and inflation: The implications of analysts' earnings forecasts. Review of Economics and Statistics 84, 632-648.

[76]. Siregar, R.Y., and Goo, S., 2010. Effectiveness and commitment to inflation targeting policy: Evidence from Indonesia and Thailand. Journal of Asian Economics 21, 113-128

[77]. Solnik, B., 1983. The relation between stock prices and inflationary expectations: the international evidence. Journal of Finance 3548.

[78]. Spyrou, S.I., 2004. Are stocks a good hedge against inflation? Evidence from emerging markets. Applied Economics 36, $41-48$.

[79]. Stulz, R.M., 1986. Asset pricing and expected inflation. The Journal of Finance 41, 209-223.

[80]. Unit, E.I., and Britain, G., 2005. Asia's Tsunami: The Impact. Economist Intelligence Unit.

[81]. Vu, T.K., 2012. The Causes of Recent Inflation in Vietnam: Evidence from a VAR with Sign Restrictions. Tokyo Center for Economic Research E-43.

[82]. Wahlroos, B., and Berglund, T., 1986. Stock returns, inflationary expectations and real activity: New evidence. Journal of Banking \& Finance 10, 377-389.

[83]. Waiquamdee, A., 2001. Modelling the inflation process in Thailand. BIS Papers chapters 8, 252-263.

[84]. Wong, K.F., and Wu, H.J., 2003. Testing Fisher hypothesis in long horizons for G7 and eight Asian countries. 1. Applied Economics Letters 10,917-923.

[85]. Wongbangpo, P, and Sharma, S C, 2002. Stock market and macroeconomic fundamental dynamic interaction: ASEAN-5 countries. Journal of Asian Economics 13, 27-51.

[86]. Zhao, X.Q., 1999. Stock prices, inflation and output: evidence from China. Applied Economics Letters 6, 509-511. 